\title{
Improving Flunked English Majors Performance through Enhancing Students' Perception of Self-Efficacy and Outcome Expectancy at Shaqra University
}

\author{
Samah Ahmed Mohammed Elborolosy ${ }^{1} \&$ Aziza Abdullah Abdulaziz Al Thenyan ${ }^{1}$ \\ ${ }^{1}$ English Department, Faculty of Science \& Humanities, Shaqraa University, Kingdom of Saudi Arabia \\ Correspondence: Samah Ahmed Mohammed Elborolosy, English Department, Faculty of Science \& Humanities, \\ Shaqraa University, Kingdom of Saudi Arabia.
}

Received: July 12, 2020

doi: 10.5539/elt.v13n9p83
Accepted: August 17, 2020

Online Published: August 20, 2020

\begin{abstract}
Teachers have to support flunked English majors emotionally, academically and use creative methods to improve their academic performance. The present research examined the effect of self-efficacy and outcomes expectancy on improving the performance of flunking English majors at Shaqra' University. The instruments required for the research were a follow-up interview, pre-posttests and a questionnaire of self-efficacy and outcomes expectancy. The sample size was thirty of flunking English major students. The research compared eight techniques to enhance self-efficacy and outcomes expectancy to regular method. To test the hypotheses, data were collected and statistically analyzed. The results showed that there was no significance difference between the control group and experimental related to regular method in the pre-tests, whereas there was a difference in the post-tests in favor of the experimental group attributed to the treatment. The findings of the questionnaire proved that students' perception of self-efficacy and outcome expectancy were crucial to enhance students' academic performance. The research suggested further investigations to examine the effect of self-efficacy and outcome expectancy on enhancing language oral and written skills.
\end{abstract}

Keywords: Flunked students, English majors, self-efficacy, outcomes expectancy, academic performance

\section{Introduction}

Supporting students in classrooms is the main goal that teachers seek to achieve. Flunked students suffer complicated problems during learning their academic courses such as negative attitudes towards courses, low motivation, misunderstanding of syllabus content, lack of skill requirements, inadequate preparation for exams and inability to manage time. Both teachers and students have a great challenge to overcome these problems and build skills that can help them to achieve success in their academic courses. To make a change to achieve success teachers have to take an action plan, make decisions, have the resiliency to accomplish the required goals, give choices, build skills on previous experience and support students emotionally and mentally through specific encouragement.

To change the performance of students, teachers need to alter expectations of the learners it could happen through self-efficacy that is considered as the effective instrument to produce the desired outcomes. Self-efficacy is an ideal strategy that can help to make positive changes, it is the inner and essential desire that directed students to accomplish tasks. Self-efficacy influences strongly the students' abilities and beliefs so that, teachers have to empower high levels of self-efficacy to motivate them and overcome obstacles and go off well. The interrelationship between self-efficacy and outcome expectancy is the powerful predictor in the determination of the students' behaviors, when it is achieving, it directly leads to the desired outcomes. Hence, outcome expectancy is influential in deciding the degree to which students can achieve particular goals. Both are using to enhance and support tasks to complete the desired goals and overcome any obstacles.

There are few researches that examined the causes of academic failure and the reasons that contributed to flunk courses for more than one unit; Ajjawi et al. (2019) stated that university students had many factors that attribute academic failure, such as negative emotion, lack of communication, students' inability to understand the material sufficiently and student's lifestyle. Also, Cherif et al. (2013) stated that approximately 370,000 students repeated courses every year in the United States of America for many reasons, such as teacher's methods of teaching, the 
materials used and damage to students' self-esteem and psychological state. Similarly, Boweles \& Brindle (2017) identified the factors those caused students' retention rates in the following factors, lack of self-confidence, attitude, beliefs, supported programs, qualified staff, and college policy. Similarly, Brooker \& Lawrence (2017) concluded that the most important problems are managing time, workload, others' expectations, and the methods of tackling these problems.

Researchers and practitioners have determined the importance of self-efficacy and outcome expectancy in enhancing teaching and learning processes. Domenech-Betoret et al. (2017) indicated that the process expectancy is the positive feelings that students gained during the positive interaction with their teacher during the course, which leads to the expectation of passing the course and this is based on understanding of students' self- beliefs as self-efficacy. Whereas, Valdebenito (2017) assured the direct connection between self-efficacy and students' performance, motivation, instructional practice, teaching behavior and enthusiasm. Additionally, Tiyuri (2018) showed that self-efficacy is the best method to assess the effectiveness of the training programs and identifying problems and weaknesses that facing students during the learning process.

\section{Context of the Problem}

On checking level four students' repeating rates in the American Literature course, results revealed that thirty students flunked the course for more than one unit. Students' repetition of the course varied between twice to five times, and they previously, had problems and difficulties during learning this course. Hence, students' perception of self-efficacy, outcome expectancy and the techniques adopted by the teacher may compensate for information processing weaknesses students suffer from through emphasizing strengths and consequently help them to pass the course and improve their academic rates.

\section{Statement of the Problem}

Thirty English majors at level four flunked the American Literature course for more than one time and were unable to pass the course. The present research examined the effect of self-efficacy and outcome expectancy on improving academic performance of flunking English major students.

\section{Questions of the Research}

1-What are the causes of repeating the American Literature course for more than one unit?

2-What are the effects of the regular method on the American Literature course?

3-What are the effects of the treatment on the American Literature course?

4-To what extent do students' perception of self-efficacy and outcome expectancy affect their performance rates in the American Literature course?

\section{Hypotheses of the Research}

1- There is a statistically significant difference at .05 level between the mean scores obtained by the study groups in the American Literature course due to the regular method in the American Literature course.

2 - There is a statistically significant difference at .05 level between the mean scores obtained by the experimental group students and those of the control group in the American Literature course due the treatment.

3- There is a statistically significant difference at 0.05 levelbetween the mean scores obtained by the study groups due to students' perception towards self-efficacy and outcome expectancy.

\section{Theoretical Background}

Najimi (2013) defined Academic failure as the aspects that led to withdrawing, flunk to achieve the grade or get low scores; the present study defined flunked students as students' retention of the American Literature course more than one unit related to specific factors. Dinther, Filip, and Segers (2011) defined self-efficacy as the confidence to success in changing behaviors for better performance, whereas Hopper (2019) defined it as the effect of certain factors on the engagement of the specific tasks that led to desirable behaviors; the present research defined self-efficacy as the students' belief that they have abilities, positive feelings, and productive engagement in tasks to achieve success in the American Literature course. Ernst (2014) defined outcome expectancy that the belief that the change of behaviors led to positive results and success; the present research defined outcome expectancy as how the students interact positively with their teacher during tasks and how they expect to fulfill goals and pass the American Literature course. Academic performance is defined by De FátimaGoulão (2014) as the outcomes of educational targets and goals to complete their degree at schools or universities; according to the present research academic performance means the final results of the students' achievements in the American Literature course based on objectives and goals of the course description provided 


\section{by Shaqra' University.}

\subsection{Related-Studies}

The interrelationship between self-efficacy and outcome expectancy was investigated by Abid \& Frahat (2019) at a higher level of learning the participants were 180 using interviews to collect data. Results showed the significant connection between self-efficacy and academic performance and affected the results in exams. Similarly, Domenech-Betoret et al. (2017) explored the relationship between students' academic achievement and their expectancy beliefs, teaching process and self-efficacy. Participants were 797 Spanish secondary students. The instruments based on value scales of self-efficacy and expectancy. The results proved that process achievement expectancy was determined by self-efficacy and academic achievement. Similarly, few researches proved that students with high self-efficacy had the highest GPA as Koseglu (2015) investigation of the effect of self-efficacy on the academic achievement of sophomore university students. Participants were 214 enrolled in various departments. The results indicated that there was a direct connection between self-efficacy and GPA and students also posses high level of self-confidence in their academic performance.

Related researches were conducted to explore the relationship between self-efficacy and academic achievement. The studies' results indicated that self-efficacy and self-regulation are basic elements in achieving academic progress, and the degrees of the students affected by the level of self-efficacy (Motlgh \& Souri, 2011; Njega \& Ndung'u, 2019). The impacts of self-efficacy on academic outcomes was investigated by Noreen, Hasan \& Ali (2018) through students' engagement. Results indicated that self-efficacy influenced directly and indirectly students' outcomes and engagement.

Self-efficacy and outcome expectancy should be high and stressed during learning and teaching processes to achieve academic goals and improve skills, Oyuga et al. (2019) investigated a study to examine the relationship between self-efficacy and academic performance among secondary school students. The sample was 300 students assigned to answer the questionnaire of self-efficacy skills. The results showed that students achieve an enhancement in their skills that related to the positive relationship between self-efficacy and academic performance.

\section{Methodology}

\subsection{Design of the Study}

The present research followed the quasi-experimental design. The participants were a few number of thirty flunked students, divided into an experimental group and a control group which exposed both to regular method then the experimental exposed to the treatment, whereas the control continued the regular method.

\subsection{The Participants of the Study}

Two groups of thirty students from level four in the English Department, at Shaqra University, Kingdom of Saudi Arabia participated in the experiment. The sample was purposely selected. Participants were divided into an experimental group and a control group each contained fifteen students, they answered quizzes, tests and participated in the piloting of the interview and questionnaire. Each participant had a unified serial number during all the stages of the experiment. The participants' age was between 21-23. Their level was low, all of them flunked the course for more than one time. Three of them repeated the course for five times, seven of them repeated the course for four times, six for three times, fourteen for twice. All the students had the same qualities, they were unwilling to accomplish the course, had low self-confidence, negative attitude, hopeless, depressed, low motivated, and they had high anxiety because of times of repetition. The participants were provided with enough information for the experiment, its stages, the ways of evaluation, and their rights to withdraw if they would like. All the participants shared in the experiment.

\subsection{The Instruments of the Study}

1- A follow-up interview.

2- Tests (quizzes-midterms-final exam).

3- Questionnaire of self-efficacy and outcomes expectancy.

\subsection{Teaching Procedures}

The duration of the present experiment lasted for sixteen weeks in the second semester for the academic year 2018/2019. This research compared the effects of regular methods to the techniques used to enhance self-efficacy and outcome expectancy through the administration of ten quizzes two midterm exams and final exam. The research had three teaching stages. The first stage, teacher followed the regular method in teaching 
based on the classroom direct instruction in the light of sustained feedback for six weeks, the students during this stage received four quizzes in four consecutive lectures and in the sixth week they received the first midterm after that, the researcher carried out an interview with the students determining the causes of low scores. The second stage, firstly, students responded to the questionnaire of self-efficacy and outcome expectancy then teacher used the techniques that enhance self-efficacy and sustain outcome expectancy (Table 1) below shown the techniques, tasks, and materials used in the experimental group, whereas the control group received the regular method. During the use of intervention, both experimental and control groups received five quizzes in five consequence weeks and at the seventh week they carried out the second midterm as the post tests. The third stage, the students performed the final exam at the last stage of evaluation.

Table 1. Procedures of the study that experimental group applied

\begin{tabular}{|c|c|c|c|c|c|c|c|}
\hline Preparation & $\begin{array}{l}\text { Learning in } \\
\text { chunks }\end{array}$ & $\begin{array}{l}\text { Oral and visual } \\
\text { presentation } \\
\text { for the data }\end{array}$ & Specific tasks & $\begin{array}{l}\text { Regular } \\
\text { encouragement }\end{array}$ & $\begin{array}{l}\text { Feedback } \\
\text { And } \\
\text { observation }\end{array}$ & quiz & $\begin{array}{l}\text { Evaluation } \\
\text { and } \\
\text { modification }\end{array}$ \\
\hline $\begin{array}{l}\text { The teacher } \\
\text { asked the } \\
\text { students to read } \\
\text { the required } \\
\text { topic at home } \\
\text { before coming } \\
\text { class based on } \\
\text { the } \\
\text { pre-experience } \\
\text { and write their } \\
\text { notes }\end{array}$ & $\begin{array}{l}\text { The teacher } \\
\text { explained in } \\
\text { chunks and } \\
\text { made stops } \\
\text { where is } \\
\text { necessary }\end{array}$ & $\begin{array}{l}\text { After } \\
\text { introducing the } \\
\text { piece of } \\
\text { information } \\
\text { teacher } \\
\text { introduce visual } \\
\text { data using a } \\
\text { projector after } \\
\text { that he asked the } \\
\text { students to make } \\
\text { an unseen oral } \\
\text { presentation, ss } \\
\text { works in groups } \\
\text { or peers }\end{array}$ & $\begin{array}{l}\text { Peer-discussion } \\
\text { Teachers asked } \\
\text { the students to } \\
\text { answer the } \\
\text { given questions } \\
\text { by the teacher. } \\
\text { Students } \\
\text { themselves } \\
\text { generate } \\
\text { questions and } \\
\text { answered them }\end{array}$ & $\begin{array}{l}\text { Students after } \\
\text { each step receive } \\
\text { regular } \\
\text { encouragement to } \\
\text { enhance the } \\
\text { performance and } \\
\text { support the } \\
\text { positive attitude }\end{array}$ & $\begin{array}{l}\text { The teacher } \\
\text { used three } \\
\text { types of } \\
\text { peer-feedback, } \\
\text { self, implicit } \\
\text { and explicit } \\
\text { feedback }\end{array}$ & $\begin{array}{l}\text { Teacher } \\
\text { examined the } \\
\text { student at the } \\
\text { beginning of } \\
\text { the next } \\
\text { lecture } \\
\text { through } \\
\text { quizzes to } \\
\text { evaluate their } \\
\text { performance } \\
\text { rate in the } \\
\text { previous } \\
\text { lecture }\end{array}$ & $\begin{array}{l}\text { After } \\
\text { correction of } \\
\text { the quiz } \\
\text { teacher } \\
\text { evaluated the } \\
\text { situation and } \\
\text { modified the } \\
\text { performance } \\
\text { through } \\
\text { sustained } \\
\text { skills }\end{array}$ \\
\hline
\end{tabular}

\subsection{Homogeneity between Groups in the Tests}

The results, shown in Table 2 below, indicated that there was no significant difference detected between the mean ranks attained by the two groups of the study in the pretest. Therefore, the two groups were assumed to be statistically equivalent on the pretest and any difference in the results of the posttest could be attributing to the treatment.

Table 2. Results of the independent sample non-parametric Mann-Whitney test on the first midterm pretest $(\mathrm{df}=$ 28)

\begin{tabular}{lllll}
\hline Groups & Mean Ranks & Sum of Ranks & Z & Sig. \\
\hline Experimental group & 16.7 & 250.5 & \multirow{2}{*}{0.757} & \multirow{2}{*}{0.461} \\
\hline Control Group & 14.3 & 214.5 & & \\
\hline
\end{tabular}

\subsection{Reliability of American Literature Tests}

The reliability coefficient showed that Pearson correlation coefficient computed of the $1^{\text {st }}$ midterm, the $2^{\text {nd }}$ midterm and $3^{\text {rd }}$ final tests was 0.876 which was significant at 0.01 level. It also indicated that the Cronbach's Alpha of these tests was .815 which indicated that the tests were reliable.

Table 3. Results of Cronbach's Alpha Tests Reliability

\begin{tabular}{ll}
\hline Cronbach's Alpha & N of Items \\
\hline 815 & 3
\end{tabular}

\subsection{The Questionnaire of Self Efficacy and Outcomes Expectancy, its Validity and Reliability}

The questionnaire consisted of a list of (16) characteristics self-efficacy items' number were 2-6-8-10-11-12-14-16 and outcome expectancy items' number were 1-3-4-5-7-9-13-15. The students indicated the degree by marking whether they (5) strongly agree, (4) agree, (3) neutral, (2) disagree, or (1) strongly disagree. The reliability coefficient showed that Cronbach Alphab was (0.731) for self-efficacy items and $(0.798)$ for outcome expectancy items which are significant at 0.01 which meant that the questionnaire was reliable for 
administration. Validity was measured by the entire consistency through Pearson Correlation (Table 11, 12).

Table 4. Results of Cronbach Alpha questionnaire reliability Statistics

\begin{tabular}{llc}
\hline Cronbach's Alpha & N of Items & Items of questionnaire \\
\hline .731 & 8 & Self-efficacy \\
.798 & 8 & Outcome expectancy
\end{tabular}

\section{Presentation of Results and Discussions}

The research displayed a set of descriptive statistics and applied a normal distribution test for all variables of the research to select an appropriate statistical testing for the set of paper variables in the following table. Table 5 below summarized thedescriptive data statistics for all variables.

Table 5. Descriptive Data Statistics for all Variables

\begin{tabular}{|c|c|c|c|c|c|c|}
\hline var & mean & std & $\begin{array}{l}\text { Kolmogorov- } \\
\text { Smirnov }^{\text {a }} \text { statistic }\end{array}$ & $\begin{array}{l}\text { Normality } \\
\text { value }\end{array}$ & p. graph & \\
\hline $\begin{array}{l}\text { Quizzes results before the } \\
\text { start of the experiment in the } \\
\text { control group }\end{array}$ & 5.533 & 2.645 & .200 & 0.2 & I & Fin- \\
\hline $\begin{array}{l}\text { Quizzes results before the } \\
\text { start of the experiment in the } \\
\text { experimental group }\end{array}$ & 5.010 & 1.641 & .200 & 0.2 & & 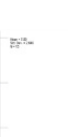 \\
\hline $\begin{array}{l}\text { The results of the first } \\
\text { midterm exam of the control } \\
\text { group }\end{array}$ & 8.67 & 2.323 & .200 & 0.2 & & $m$ \\
\hline $\begin{array}{l}\text { The results of the first } \\
\text { midterm exam of the } \\
\text { experimental group }\end{array}$ & 9.33 & 3.492 & .163 & 0.04 & & - \\
\hline $\begin{array}{l}\text { Quizzes results during } \\
\text { applying the experiment in } \\
\text { the control group }\end{array}$ & 4.60 & 2.32 & .200 & 0.2 & & 程: \\
\hline $\begin{array}{l}\text { Quizzes results during } \\
\text { applying the experiment in } \\
\text { the experimental group }\end{array}$ & 7.38 & 2.11318 & .200 & 0.2 & 1 & \\
\hline $\begin{array}{l}\text { The results of the second } \\
\text { term exam of the control } \\
\text { group }\end{array}$ & 9.27 & 5.2 & .147 & 0.04 & & - \\
\hline $\begin{array}{l}\text { The results of the first } \\
\text { second term exam of the } \\
\text { experimental }\end{array}$ & 14.5333 & 4.22352 & .140 & 0.04 & 1 & 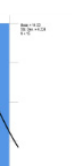 \\
\hline
\end{tabular}




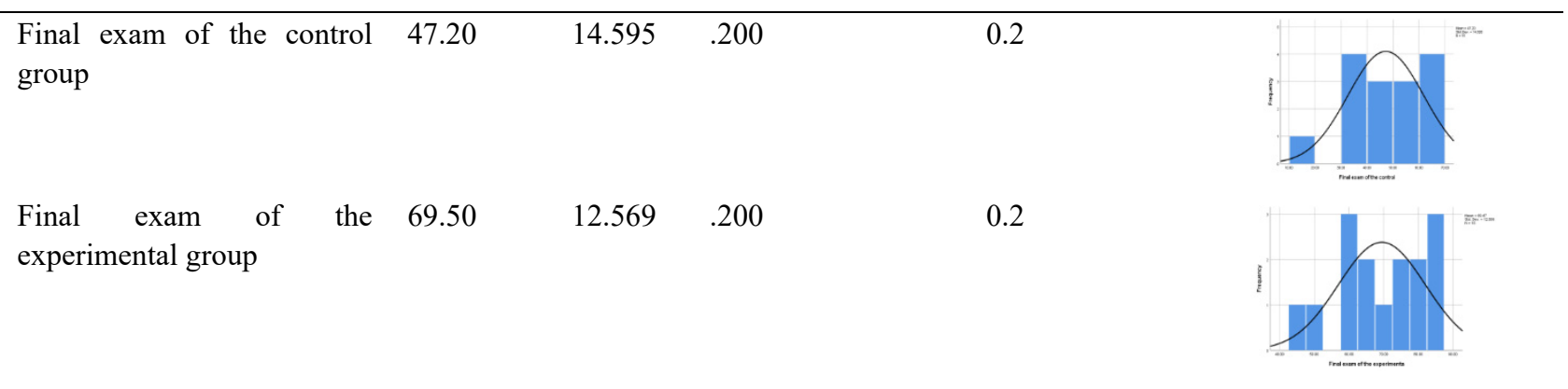

Table 5 above indicated the mean, standard deviation, Kolmogrov-Smirnov statistics and normality for the pre-post quizzes, the pre-first midterm and the post second midterm and final exam, which conducted for the student. Also, the normality test indication, its p. value and normal distribution graphs to determine that either to use parametric or nonparametric statistics to examine the effectiveness of the techniques used to improve self-efficacy and outcome expectancy and students' perception of them, the research found that all variables were normally distributed except the first and second midterm data.

A set of descriptive and inferential statistics was used to test this hypothesis. What are the causes of repeating the American Literature course for more than one unit? The researchers carried out a follow-up interview consisted of a checklist of ten open-ended questions were answered by the students. The results of the interview proved that 98\% of the students faced problems during learning the American Literature course, the students' comments were as follows: the course is so hard and contained a lot of complicated terminology, the previous teachers' styles of teaching weren't proper to them, they had a negative attitude towards the course because of times of retention, they were obliged to take the course, they couldn't drop it out, because it was a zero level. Previous teachers were hard to understand. Changing teachers every semester participated in repeating the course, they also didn't receive enough encouragement, the assessment wasn't enough, just one midterm and final exam, and finally they have inadequate study habits and procrastination till the final moments.

A set of descriptive and inferential statistics was used to test this hypothesis what are the effects of regular method on the American Literature course?



Figure 1. Raw Mean Scores of the Study Groups in Quizzes with Regular method

The figure above indicated that there was no difference between the two groups with the regular methods. The parametric paired sample test was used to find out if these differences are statistically significant as shown in Table 6 below. 
Table 6. Results of the parametric paired samples test of the quizzes before the start of the experiment with regular method

\begin{tabular}{lllllll}
\hline & & Mean & $\begin{array}{l}\text { Std. } \\
\text { Deviation }\end{array}$ & $\mathrm{t}$ & $\mathrm{df}$ & Sig. (2-tailed) \\
\hline Pair 1 & $\begin{array}{l}\text { Experimental } \\
\text { group 1 }\end{array}$ & 5.0100 & $-.866-$ & -.866 & 14 & \\
& $\begin{array}{l}\text { Control group2 } \\
5.5333\end{array}$ & 1.64172 & & & 401. \\
\hline
\end{tabular}

The results, shown in Table 6 above, indicated that there was no statically significant difference between the two groups due to the regular method. Sig $=(.401)$ which means rejecting of the hypothesis.

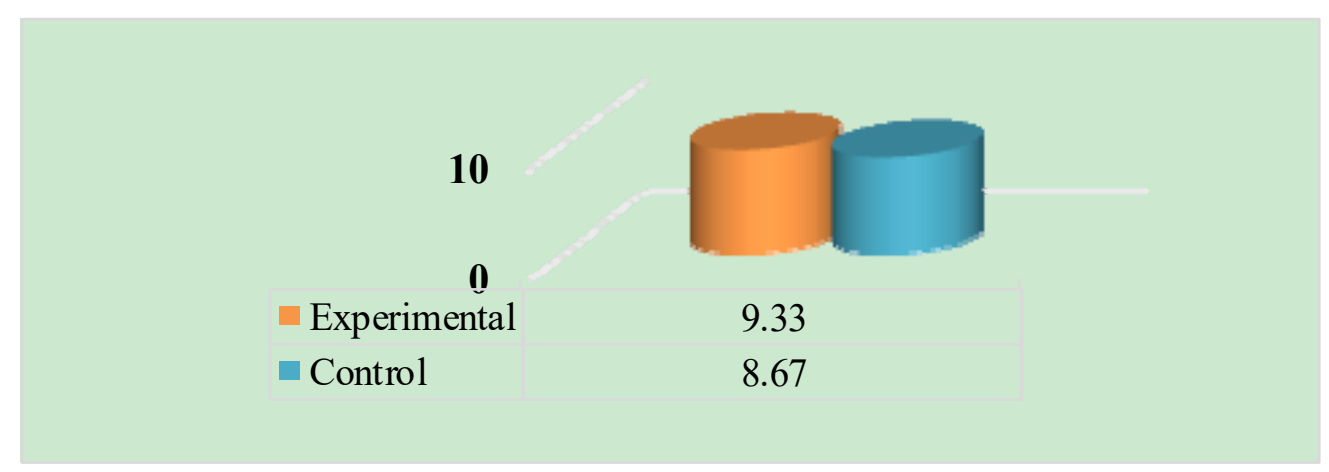

Figure 2. Raw Mean Scores of the Study Groups in the First Midterm Exam with Regular Method

The figure above indicated that the difference between the two groups was slightly in the first midterm exam after using the regular methods in teaching the course. The independent sample, non-parametric Mann-Whitney test was used to find out if these differences are statistically significant as shown in Table 7 below.

Table 7. Results of the Independent Sample non-Parametric Mann-Whitney Test in First Midterm With Regular Method (pretest df $=28$ )

\begin{tabular}{lllll}
\hline Groups & Mean Ranks & Sum of Ranks & $\mathbf{Z}$ & Sig. \\
\hline Experimental group & 16.7 & 250.5 & 0.757 & 0.461 \\
\cline { 1 - 3 } Control Group & 14.3 & 214.5 & &
\end{tabular}

The results, shown in Table 7 above, indicated that there was no significant difference detected between the mean ranks attained by the two groups of the research in the first midterm test, which means rejecting of the hypothesis, there was no significant differences between the mean scores attained by the study groups due the regular method.

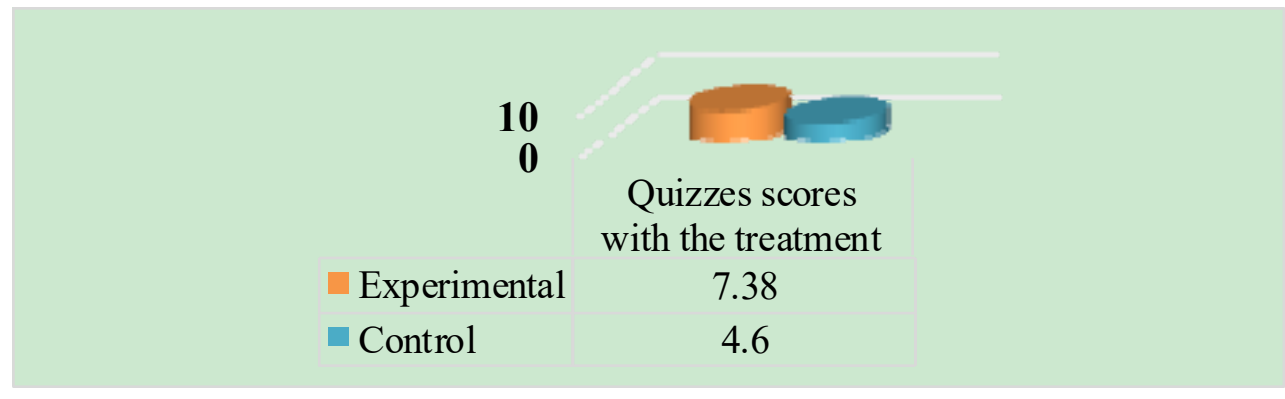

Figure 3. Raw Mean Scores of the Study Groups in Quizzes with the Treatment

The figure above showed that there was a difference between the two groups with the intervention. The parametric Paired Sample Test was used to find out if these differences are statistically significant as shown in 
Table 8 below.

Table 8. Results of the Parametric Paired Samples Test Quizzes after the Start of the Experiment with Treatment

\begin{tabular}{cccccc}
\hline & Mean & Std. Deviation & T & df & Sig. (2-tailed) \\
\hline $\begin{array}{c}\text { Pair 1 } \\
\begin{array}{c}\text { Experimental } \\
\text { group 1 }\end{array}\end{array}$ & 7.3867 & 2.11318 & 5.183 & 14 & .000 \\
\cline { 1 - 2 } Control group & & & & & \\
\hline
\end{tabular}

The results in Table 8 above, indicated that there was a statistically significant difference between the two groups in favor of the experimental group students that could be attributed to the treatment $(\mathrm{T}=5.183)$ and $(\mathrm{Sig}=.000)$.

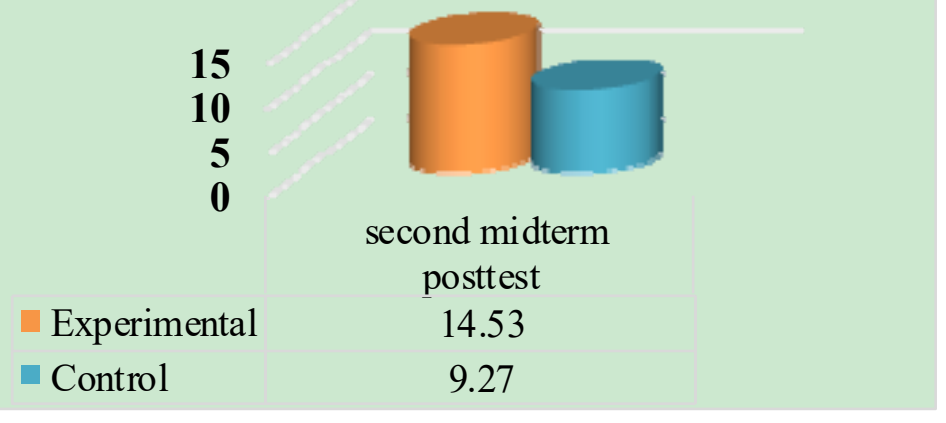

Figure 4. Raw Mean Scores of the Study Groups in Second Midterm Exam

The figure above is shown that there was an observable difference between the mean scores of both groups in the posttest of the second midterm after using the treatment in favor of the experimental group students. The independent sample, non-parametric Mann-Whitney test was used to find out if these differences are statistically significant as shown in Table 9 below.

Table 9. Results of the Independent Sample non-Parametric Mann-Whitney Test in Second Midterm Posttest $(\mathrm{df}=$ 28)

\begin{tabular}{lllll}
\hline Groups & Mean Ranks & Sum of Ranks & $\mathbf{Z}$ & Sig. \\
\hline Experimental group & 20.6 & 309.0 & 3.182 & 0.001 \\
\hline Control Group & 10.4 & 156.0 & & \\
\hline
\end{tabular}

The results, are shown in Table 9 above, indicated that there was a statistically significant difference detected between the mean ranks attained by the two groups of the study in favor of the experimental group students due to the techniques used in the experimental group.

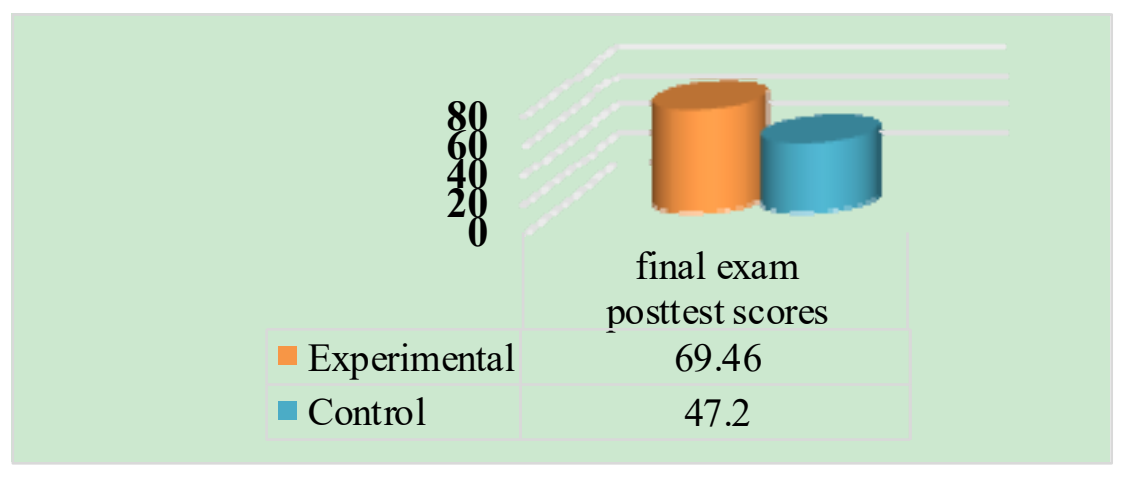

Figure 5. Raw Mean Scores of the Study Groups in the Final Exam Posttest

The figure above is shown that there was an observable difference between the mean scores of both groups in the posttest of the final exam in favor of the experimental group students. Paired Samples Test was used to find out if these differences were statistically significant as shown in Table 10 below. 
Table 10. Results of the Parametric Paired Samples Test of the Final Exam

\begin{tabular}{|c|c|c|c|c|c|c|c|}
\hline & & Mean & $\begin{array}{c}\text { Std. } \\
\text { Deviation }\end{array}$ & $\begin{array}{l}\text { Std. Error } \\
\text { Mean }\end{array}$ & $\mathrm{t}$ & $\mathrm{df}$ & $\begin{array}{c}\text { Sig. } \\
\text { (2-tailed) }\end{array}$ \\
\hline \multirow[t]{2}{*}{ Pair 1} & $\begin{array}{c}\text { Final exam of the } \\
\text { experimental }\end{array}$ & 69.4667 & 12.56 & & 5.301 & 14 & .000 \\
\hline & $\begin{array}{c}\text { Final exam of the } \\
\text { control }\end{array}$ & 47.2000 & 14.59 & & & & \\
\hline
\end{tabular}

The results indicated that there was a statistically significant difference detected between the mean attained by the two groups of the study in the final exam in favor of the experimental group, $\mathrm{T}=(5.301)$ and $\mathrm{Sig}=(.000)$.

A set of descriptive and inferential statistics were used to test this hypothesis: To what extent students' perception of self-efficacy and outcome expectancy affect their performance in the American Literature course?

Table 11. Descriptive Statistics of Self-efficacy Items

\begin{tabular}{lllll}
\hline & Mean & Std. Deviation & $\begin{array}{l}\text { Pearson } \\
\text { Correlation }\end{array}$ & $\begin{array}{l}\text { Sig. } \\
\text { (2-tailed) }\end{array}$ \\
\hline Var10 & 4.2000 & .84690 & .760 & .000 \\
Var16 & 3.9667 & .80872 & .703 & .000 \\
Var12 & 3.9667 & .92786 & .493 & .006 \\
Var11 & 3.9000 & .88474 & .596 & .001 \\
Var8 & 3.7667 & .77385 & .521 & .003 \\
Var6 & 3.5000 & 1.13715 & .670 & .000 \\
Var14 & 3.3667 & 1.03335 & .479 & .007 \\
Var2 & 3.1667 & 1.08543 & .702 & .000 \\
\hline
\end{tabular}

There were significant differences at .05 level among the mean scores obtained by the research group due to students' perception of self-efficacy. The frequency variables, statistical results of self-efficacy items revealed that the higher ones were var10"I will modify my performance if I make oral and visual presentations" $(\mathrm{M}=$ $4.2000)$, sig. $=\left(.000^{*}\right)$, then var16 "I will have a challenge to master the items of the American literature course this semester" $(\mathrm{M}=3.9667)$, sig. $=(.000 *)(\mathrm{M}=3.1667)$, sig. $=\left(000^{*}\right)$. The lowest item was var2"- I will change my previous negative beliefs about course" $(\mathrm{M}=3.1667)$, sig. $=\left(.000^{*}\right)$.

Table 12. Descriptive Statistics of Outcomes Expectancy Items

\begin{tabular}{lllll}
\hline & Mean & Std. Deviation & $\begin{array}{l}\text { Pearson } \\
\text { Correlation }\end{array}$ & $\begin{array}{l}\text { Sig. } \\
\text { (2-tailed) }\end{array}$ \\
\hline Var13 & 4.0667 & .78492 & .871 & .000 \\
Var7 & 4.0333 & .66868 & .727 & .000 \\
Var4 & 4.0000 & .87099 & 811 & .000 \\
Var9 & 3.9333 & .78492 & .818 & .000 \\
Var15 & 3.9000 & .71197 & .721 & .000 \\
Var5 & 3.8667 & .93710 & .861 & .000 \\
Var3 & 3.5667 & 1.10433 & .854 & .000 \\
Var1 & 3.5000 & .86103 & .802 & .000
\end{tabular}

There were significant differences at .01 level between the mean scores obtained by the research group due to students' perception of outcome expectancy. The frequency variables, statistical results of outcome expectancy items revealed that the higher ones were var13"I have high outcome expectancy to achieve difficult goals this semester" $(\mathrm{M}=4.0667)$, sig. $=\left(.000^{*}\right)$. Then, var7" I expect to pass the course if my teacher gives me continues evaluation" $(\mathrm{M}=4.0333)$, sig. $\left(.000^{*}\right)$. The lowest item was for var1" I expect that the strategies that used before in the American Literature course will help me to pass the course" $(\mathrm{M}=3.5000)$, sig. $=\left(000^{*}\right)$. 


\section{Conclusions}

1- Flunked English majors in the American Literature course confronted serious problems, so that the present research examined the causes of repeating the course more than one unit and treated these problems by enhancing the performance of students through techniques and continuous assessment to improve students' self-efficacy and outcome expectancy.

2- The research identified students' weak points through a follow-up interview that helped the researchers to design the plan of treatment.

3- Based on the findings of the study, the results were discussed according to three stages:

A- In the first stage, the researchers evaluated the students' performance after using the regular method in both groups the mean of quizzes in the control $=(5.01)$ whereas in the experimental $=(5.53)$ also, the results of the first midterm exam in the control $=(8.67)$ whereas in the experimental $=(9.33)$ which indicated that the level of in both groups was approximately the same and there was no difference between them due to the regular method.

B- In the second stage, the researchers evaluated the students' performance after using the treatment in both groups the mean of quizzes in the control $=(4.60)$ whereas, in the experimental $=(7.38)$ also, the results of the second midterm exam in the control $=(9.27)$ whereas in the experimental $=(14.53)$ which that proved the effectiveness of the treatment used in favor of the experimental group.

C- In the third stage, there was a final evaluation to compare the results of the final exam and determined the percent of success, the means of final exam in the control $=(47.2)$ whereas in the experimental $=(69.50)$ also the percent of passing students in the control group $=(26 \%)$ whereas in the experimental group $=(87 \%)$.

4- Students' response to the questionnaire of self-efficacy and outcome expectancy indicated that students had a positive attitude towards the course when using the techniques that support self-efficacy and outcome expectancy.

5- The results concluded that techniques used to improve self-efficacy and students' outcome expectancy proved to be effective in enhancing students' performance in the American Literature course at Shaqra' University and helped students to pass the course.

\section{Implications}

The results of the present research may be used in teaching students who repeated the course more than one unit to improve their performance. By scanning the results of courses in the next semester there were a lot of students who flunked varies courses in the English department. The percent of flunked students in Linguistics1 was (50\%) whereas in the introduction to literary skills was (47\%) and in General English was (52\%) so that, the researchers recommend applying this method of teaching comparing results.

\section{Recommendations}

According to the results of the present research, well planned strategies should be based on supporting self-efficacy and outcome expectancy that are needed to improve repeaters' performance. Moreover, English language courses should be taught through stressing the role of self-efficacy in getting high outcomes to improve all the language skills. Technicalities that used in teaching American Literature course should be stressed in teaching English language literature courses, in order to help and support students passing courses smoothly. More studies are needed to examine the impact role of self-efficacy and outcome expectancy in enhancing oral and written language.

\section{References}

Abid, M., \& Frahat, S. (2019). The effect of self-efficacy on academic performance at higher learning. A case study of Punjab University Lahore. Journal of Educational Science and Research, 6(1), 33-47.

Ajjawi, R., et al. (2019). Persisting students' explanations of and emotional responses to academic failure. Journal of Higher Education Research \& Development, 39(2), 185-199. https://doi.org/10.1080/07294360.2019.1664999

Bowles, T. V., \& Brindle, K. A. (2017). Identifying facilitating factors and barriers to improving student retention rates in tertiary teaching courses: A systematic review. Higher Education Research \& Development, 36(5), 903-919. https://doi.org/10.1080/07294360.2016.1264927

Brooker, A., Brooker, S., \& Lawrence, J. (2017). First year students' perceptions of their difficulties. Student Success, 8(1), 49-62. https://doi.org/10.5204/ssj.v8i1.352 
Cheirf, A. H., \& Movahedzadeh, F. (2013). Why do students fail? students' perspective. Retrieved from https://www.researchgate.net/publication/274310752

De FátimaGoulão, M. (2014). The Relationship between self-efficacy and academic achievement in adults' learners. Athens Journal of Education, 1(3), 237-246. https://doi.org/10.30958/aje.1-3-4

Dinther, V., Filip, M., \& Segers, M. (2011). Factors affecting students' self-efficacy in higher education. Educational Research Review, 6(2), 95-108. https://doi.org/10.1016/j.edurev.2010.10.003

Domenech-Betoret, F. et al. (2017). Self-efficacy, satisfaction, and academic achievement: The mediator role of students' expectancy-value beliefs. Frontiers in Psychology. https://doi.org/10.3389/fpsyg.2017.01193

Ernst, D. (2014). Expectancy theory outcomes and student evaluations of teaching. Journal of Educational Research and Evaluation, 20(7-8). https://doi.org/10.1080/13803611.2014.997138

Hopper, E. (2019). Understanding self efficacy. Thought Co. Retrieved from https://www.thoughtco.com/self-efficacy-4177970

Koseoglu, Y. (2015). Self efficacy and academic achievement: A case from Turkey. Journal of Education and practice, 6(29), 1-11. Retrieved from https://eric.ed.gov/?id=EJ1081281

Motlgh, E., \& Souri, H. (2011). The relationship between self-efficacy and academic achievement in high school students. Journal of Procedia-Scoial Behsavioural Science, 15(1), 705-768. https://doi.org/10.1016/j.sbspro.2011.03.180

Najimi, A. (2013). Academic failure and students' viewpoint: The influence of individual, internal and external organizational factors. Journal of Educ Health Promot, 2(22). https://doi.org/10.4103/2277-9531.112698

Njega, S. W., Njoka, J. N., \& Ndung'u, C. W. (2019). Assessment of self-efficacy on learners' academic performance in secondary schools in Kirinyaga and Murang'a Counties, Kenya. Journal of Arts and Humanities, 8(10), 48-59. DOI: org/10.5281/zenodo.3756004

Noreen, S., Hasan, A., Batool, I., \& Ali, A. (2018). The Impacts of academic self-efficacy on academic outcomes: The mediating effect of student engagement. International Journal of Academic Research in Business and Social Sciences, 8(11), 315-327. https://doi.org/10.6007/IJARBSS/v8-i11/4904

Oyuga, P. A, et al. (2019). Relationship between self efficacy and academic performance among orphaned secondary school students in Kenya. International journal of psychology and Behavior Science, 9(3), 39-46. DOI:10.5923/j.ijpbs.20190903.02

Rodríguez, S. \& Cerezo, R. (2014). Teacher self-efficacy and its relationship with students' affective and motivational variables in higher education. European Journal of Education and Psychology, 7, 107-120. https://doi.org/10.30552/ejep.v7i2.106

Tiyuri, A, et al. (2018). Research self-efficacy and its relationship with academic performance in postgraduate students of Tehran University of Medical Sciences in 2016. National Liberary of Medicine, National centre for Biotechnology Information. https://doi.org/10.4103/jehp.jehp_43_17

Valdebenito, M. AB. (2017). Self-efficacy and academic experience with university students. ActaColombianaDe Psicologia, 20(1), 275-283. DOI.org/10.14718/ACP.2017.20.1.13

\section{Copyrights}

Copyright for this article is retained by the author(s), with first publication rights granted to the journal.

This is an open-access article distributed under the terms and conditions of the Creative Commons Attribution license (http://creativecommons.org/licenses/by/4.0/). 